Scholedge International Journal of

Management \& Development

ISSN 2394-3378, Vol.05, Issue 05 (2018)

Pg 48-58.

DOI: 10.19085/journal.sijmd050501
Published by: Scholedge Publishing

www.theSCHOLEDGE.org

Email: editorial@thescholedge.org

(C) Publisher

\title{
Customer Relationship Management and Micro, Small and Medium Enterprises (MSMEs) Growth in South West, Nigeria
}

\author{
Oladejo Dauda Adewole $(\mathrm{PhD})$ \\ Department of Entrepreneurial Studies, College of Management Sciences, \\ Federal University of Agriculture, Abeokuta, Ogun State, Nigeria
}

\begin{abstract}
This study examines the basic components of Customer Relationship Management and its influence on the growth of Micro, Small and Medium Enterprises (SMEs) in South-West Nigeria. The data obtained were analysed using appropriate descriptive and inferential statistics. The results of the study show a statistically significant relationship between customer care strategies and customer retention, public image maintenance and customer care $(r=0.430, p<0.05),(r=-$ $0.438, p<0.05)$ respectively. The analysis also revealed a significant relationship between human resource factor and business revenue, product development as well as product market development $(r=0.209, p<0.05),(r=0.259, p<0.05),(r=0.472, p<0.05)$ respectively. The analysis further showed a statistically significant relationship between analytics and business revenue, product development, and customer retention $(r=0.416, p<0.05) ;(r=0.313, p<$ $0.05)$, and ( $r=0.291) p=0.003)$ respectively. It was also found out that there was a statistically significant relationship between business reporting and employee satisfaction, customer retention, product market development and business revenue. There was also a significant relationship between marketing and business revenue $(r=0.214, p<0.05)$. The study concludes that the components of Customer Relationship Management examined as an omnibus concept had influence on the growth of MSMEs in the study area $(R$ square $=0.375$, Adjusted $R$ square $=$ $0.334, p<0.001$ ).
\end{abstract}

Keywords: Customer Relationship Management, Micro, Small, and Medium Enterprises, Public Image Maintenance, Employee Satisfaction and Retention, Product Development, Product Market Development.

\section{Introduction}

In Nigeria, the Federal government paid attention to the growth and development of Micro, Small and Medium Enterprises (MSMEs) by creating agencies like the National Directorate of Employment (NDE) that came up with programmes such as Open Apprenticeship Scheme and Graduate Employment Programmes. Literature reveals that access to credit is the engine to economic growth as it paddles the ship for the smooth and profitable operation of the private sector. However, Nigeria's private businesses suffered from getting sufficient credit and some have no access to credit at all; this is because Nigerian banks only give loans to businesses that can provide fixed assets as collateral. This shuts out MSMEs which can hardly boast of any reasonable fixed assets from getting a loan to run their business profitably. In view of this, laws

http://dx.doi.org/10.19085/journal.sijmd050501 
were laid down by the Federal Government to assist MSMEs in Nigeria to have access to loans. For instance, two bills were passed recently into Acts by the National Assembly. These are 'the Secured Transactions in Movable Assets Act, 2017' (i.e. Collateral Registry Act) and 'the Credit Reporting Act, 2017'. The Collateral Registry Bill, 2017, now gives confidence to lenders to utilise the Registry and thereby make credit available to MSMEs and individuals through the use of their assets whose useful year is up to one year such as motor cars and motorcycles as collateral. 'The Credit Reporting Act' also provides for credit information sharing between Credit Bureaus and lenders, as well as other institutions that provide services for their customers to pay later (i.e. buy now and pay later).

Nigerian government efforts at aiding the growth of MSMEs notwithstanding, MSMEs in Nigeria were observed to have suffered expected expansion due to low profit; this might be caused by low customer base arising from lack of shift from "transaction" focus to "interaction" focus by the suppliers in the exchange of goods and services. MSMEs growth could come in terms of revenue generation, public image maintenance, skill acquisition and application, employees' satisfaction and retention, product development as well as product market development.

As globalization has become the order of the day and is increasing competition among Micro, Small and Medium Enterprises (MSMEs) across the world, businesses have got to pay particular attention to attract and retain customers and the final users of their products through effective strategies to manage and retain them. In today's information-driven world, Alireza, Mostafa and Kazem (2011) submit that the customers should not remain merely as people buying goods or services from a business (i.e. transaction focus); in addition to being concerned about questions such as "what", "how many", and "how much"; they should be clever enough to ask "why". Today's customers are hard to come by, convince and are difficult to please too. They have control over what to buy, when to buy and from where to buy their desired products (goods or services). They can collect information about products, dealers, and prices before ordering a product. When a business fulfils most of their expectations, a repeat purchase from such business can occur. Therefore, effective implementation of customer relationship management components are key to attracting, nurturing and retaining customers; they bring about the interaction (relationship) between the internal business processes and functions, and external business environments, to create and deliver value to existing and potential customers profitably. Customer relationship management components have a primary goal to increase customer loyalty and in turn improve business profitability and growth.

The basic components of Customer Relationship Management (CRM) include human resource management, marketing, customer service, analytics and business reporting, as well as lead management. These components equip business concerns with the knowledge of target customers and initiatives to serve them better for an increased sales turnover and the growth of businesses in the long run. But the lack of shift from "transaction" focus to "interaction focus" often retards business growth. Customer relationships are preferred to transactional exchange as customer relationship is capable of building viable competitive advantage and enhance business growth. Alireza, Mostafa and Kazem (2011) opine that for businesses to survive in the global markets, focusing on the customer is becoming a key factor. However, inadequate implementation of the components of customer relationship management may result to inequity in handling customers, thereby defeating the purpose of good customer-supplier relationship to promote business growth; hence, this study.

\section{Statement of the Problem}

The Federal Government of Nigeria creates agencies, and laws were also laid down to assist the growth of MSMEs in the country. Her efforts at aiding the growth of MSMEs are rather leading to a mere proliferation of MSMEs in Nigeria without a remarkable growth rate; some of these firms die at the infant stage. Their death might not be unconnected with the inadequate customer base. However, MSMEs coordinators strive to find effective ways of managing and sustaining their customer base. Though, the extant literature reveals that the software vendors maintain that the use of technology for managing customer relationships could improve the customer base, but the cost 
implication of installing any CRM technology by MSMEs is enormous. Also, clients do not want to be treated just like a party for exchange, rather they want to be treated like a unique individual. Many studies show that customers are frequently frustrated by a company's lack of ability to meet their relationship expectations; companies also do not always know how to translate the data they have gained from CRM software into a feasible action plan. The literacy level of customers in the use of CRM technology was observed to be shallow and most start-ups in Nigeria are not into the use of CRM software. Alireza et al (2011) opine that organisations have to invest hugely in developing and attaining a set of diverse resources that facilitate behaviour change towards building the individual customer base when necessary for effective implementation of CRM technology. Therefore, this study assesses the factors that could influence the customer-supplier relationship to promote Micro, Small and Medium Enterprises (MSMEs) growth in Southwest, Nigeria.

Research Questions

1. What are the factors that uniquely enhance Customer Relationship Management in MSMEs in Southwest,Nigeria?

2. Is there any relationship between customer relationship management and SMEs growth in Southwest Nigeria?

3. Do factors of customer relationship management have a significant influence on SMEs growth in Southwest Nigeria?

Objectives of the Study

The general objective of the study was to assess the influence of customer relationship management components in aiding the growth of MSMEs in Southwest, Nigeria. The specific objectives were to

(i) Determine factors that uniquely enhance customer relationship management among Micro, Small and Medium Enterprises(MSMEs);

(ii) Investigate the relationship between customer relationship management and MSMEs growth in Southwest, Nigeria;

(iii) Evaluate the influence of customer relationship management on the growth of SMEs in Southwest Nigeria.

Hypotheses of the Study

1. Ho:There is no statistically significant relationship between customer relationship management (CRM) and MSMEs growth in Southwest, Nigeria.

Ha: There is a statistically significant relationship between customer relationship management (CRM) and MSMEs growth in Southwest, Nigeria.

2. Ho: There is no statistically significant influence of customer relationship management (CRM) factors on MSMEs growth in Southwest, Nigeria.

Ha: There is a statistically significant influence of customer relationship management (CRM) factors on MSMEs growth in Southwest, Nigeria.

\section{The significance of the Study}

This study contributes to the literature on the growth of MSMEs in Nigeria as it identifies the basic ingredients of customer relationship management which aid customer satisfaction; a satisfied customer keeps on being loyal to the business and spread good word-of-mouth. This can be realized by nurturing customer engagement through effective product marketing, human resource management, analytics, business reporting, and lead management. A good customer-supplier relationship could enhance the management of the existing customers as well as creates knowledge for potential customers who are yet to be the business customers; thus, a massive customer base that could lead to profits continuity for MSMEs will be established. The study also underscores the contribution of the individual factor of customer relationship management to the development of good customer-supplier relationship as well as the contribution of all the factors as an omnibus concept. The study provides information to private businesses in Nigeria on access to loans which assists them to realize their growth objective. 


\section{Conceptual Framework}

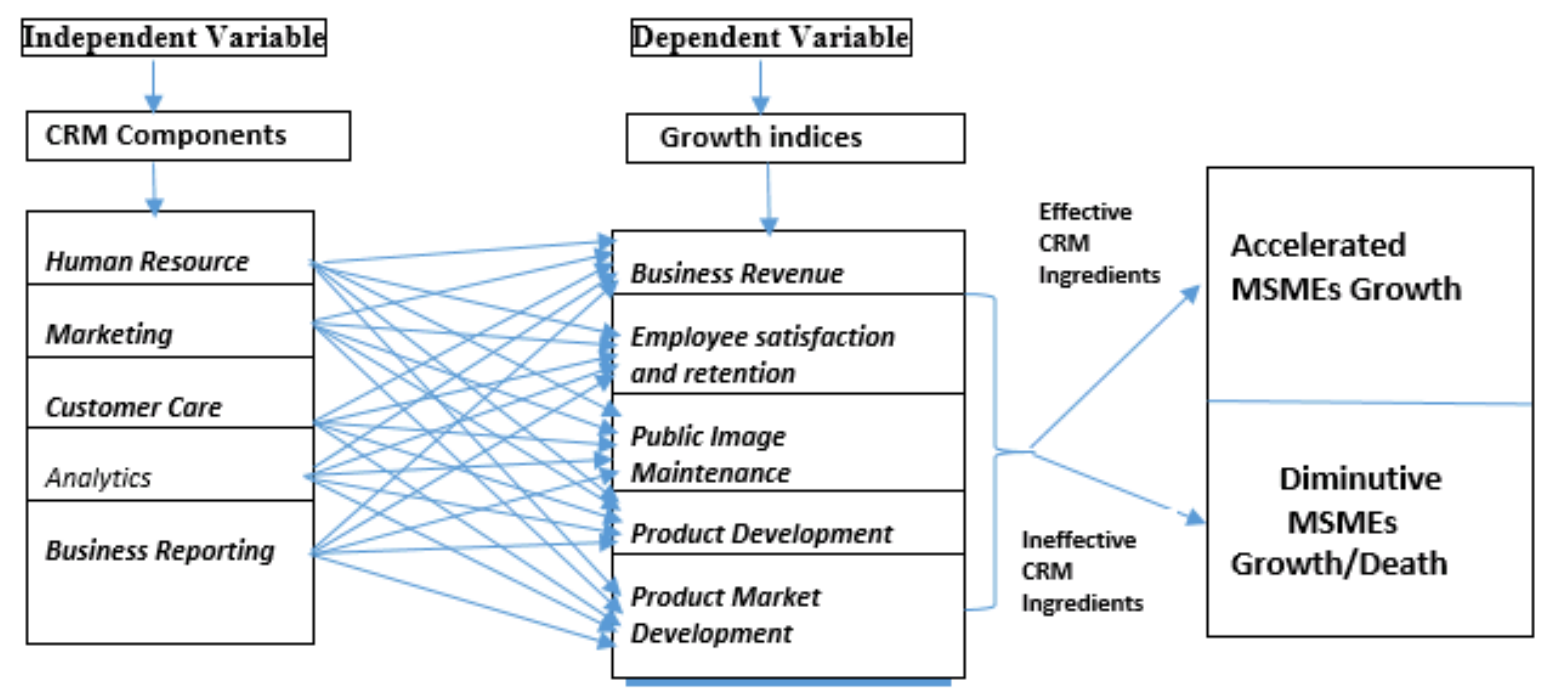

Source: Author, 2017

\section{Theoretical Review}

Theory by Industrial Marketing and Purchasing Group (IMP Group) Håkan (1982)

This Europe-based research activity in Industrial Marketing centres mostly on a two-party relationship. It could be explained as follows:

(i) Both purchaser and merchant are dynamic members in the market. Each may take part in an inquiry to locate a reasonable purchaser or vendor so as to endeavour to control the transaction procedure.

(ii) The connection amongst purchaser and merchant is much of the time long haul, close and including a perplexing example of interaction between and inside each organization. The advertisers' and purchasers' undertaking, for this situation, may have more to do with keeping up these connections than with making a direct deal or buy.

(iii) Buying and selling procedures may require critical adjustments in organization or activity by either or the two organizations. In fact, these connections can prompt clashes as well as co-activity.

(iv) Close links are frequently considered with regards to a constant crude material or segment supply.

This theory is relevant to this study as it emphasizes the following:

(a) The need to consider the overall relationship between a supplier and a customer when analysing a single purchase.

(b) The interaction between two active parties in a relationship. This means that the customers' reaction to the sellers' actions is equally important in the analysis.

(c) The stability of relationships. This stability rests on the investments which have been made in the relationship by the two parties.

(d) The similarity in the tasks of buyers and sellers.

As earlier noted, clients in the relationship do not want to be treated just like a party for exchange, rather they want to be treated like a unique individual. Many studies show that customers are frequently frustrated by a company's inability to meet their relationship expectations. 


\section{Methodology}

Research Design

The study employed the survey research design. It enables the researcher to collect information from a large population. Information obtained for this study was generalized for the entire population. The independent variable was customer relationship management. It was measured using six factors- human resource management, CRM application package, marketing, business reports, analytics, and customer care. The dependent variable was MSME growth and was measured with public image maintenance, revenue growth, employees' satisfaction and retention, product development, and product market development.

Population, Sample Size and Sampling Procedures

The population and study sample were drawn from MSMEs in Southwest Nigeria. In order to determine an adequate sample size for this study, the values of significance level, and effect size were well-thought-out to optimise sampling effort within the constraint of the available resources. Then, Krejcie and Morgan's formula was employed to ascertain the sample size for the study as follows:

$\mathrm{s}=\mathrm{X}^{2} \mathrm{NP}(1-\mathrm{P}) \div \mathrm{d} 2(\mathrm{~N}-1)+\mathrm{X}^{2} \mathrm{P}(1-\mathrm{P})$.

$\mathrm{s}=$ required sample size.

$\mathrm{X}^{2}=$ the table value of chi-square for 1 degree of freedom at the desired confidence level

$0.05=(3.841)$.

$\mathrm{N}=$ the population magnitude.

$\mathrm{P}=$ the population quantity

$\mathrm{d}=$ the degree of accuracy

Following Krejcie and Morgan's (1970) sample size table, the sample size selected for the study was 100 respondents.

Research Instruments/Measurement

A structured questionnaire and in-depth interview were used for data collection. The questionnaire was divided into three sections. The first section (SECTION A) elicited information on demographic characteristics of respondents. The second section stimulated information on customer relationship management (CRMCQ). The third section stimulated information on MSMEs growth (MSMEsGQ). Also, in-depth interviews were conducted on Human Resource Managers in the selected MSMEs with emphasis on Human resource management practices in their enterprises.

\section{Data Analysis Techniques}

Answers to the research questions and the objectives of the study were achieved by analyzing the data obtained on all variables using appropriate statistical techniques. Data Analysis Techniques 
Table 1: Analysis of Relationship between Customer Relationship Management and Micro, Small and Medium Enterprises (MSMEs) Growth

\begin{tabular}{|c|c|c|c|c|c|c|c|}
\hline & & \begin{tabular}{|c} 
Employee \\
Satisfaction/ \\
Retention \\
\end{tabular} & $\begin{array}{l}\text { Customer } \\
\text { Retention }\end{array}$ & $\begin{array}{c}\text { Product } \\
\text { Development }\end{array}$ & $\begin{array}{l}\text { Public Image } \\
\text { _Maintenance }\end{array}$ & $\begin{array}{c}\text { Product_- } \\
\text { Market_- } \\
\text { Development }\end{array}$ & $\begin{array}{l}\text { Business } \\
\text { Revenue }\end{array}$ \\
\hline \multirow{3}{*}{ Marketing } & $\begin{array}{c}\text { Pearson } \\
\text { Correlation }\end{array}$ & .068 & .117 & .098 & .058 & .123 & $.214^{*}$ \\
\hline & Sig. (2-tailed) & .501 & .248 & .330 & .568 & .225 & .032 \\
\hline & $\mathrm{N}$ & 100 & 100 & 100 & 100 & 100 & 100 \\
\hline \multirow{3}{*}{$\begin{array}{c}\text { Customer } \\
\text { Care }\end{array}$} & $\begin{array}{c}\text { Pearson } \\
\text { Correlation }\end{array}$ & .071 & $.430 * *$ & -.083 & $-.438 * *$ & -.035 & $.302 *$ \\
\hline & Sig. (2-tailed) & .481 & .000 & .412 & .000 & .733 & .909 \\
\hline & $\mathrm{N}$ & 100 & 100 & 100 & 100 & 100 & 100 \\
\hline \multirow{3}{*}{$\begin{array}{c}\text { CRM } \\
\text { Application } \\
\text { Package }\end{array}$} & $\begin{array}{c}\text { Pearson } \\
\text { Correlation }\end{array}$ & -.003 & $.326 * *$ & $.350 * *$ & -.160 & $.311 * *$ & .195 \\
\hline & Sig. (2-tailed) & .974 & .001 & .000 & .111 & .002 & .052 \\
\hline & $\mathrm{N}$ & 100 & 100 & 100 & 100 & 100 & 100 \\
\hline \multirow{3}{*}{$\begin{array}{c}\text { Human } \\
\text { Resource }\end{array}$} & $\begin{array}{c}\text { Pearson } \\
\text { Correlation }\end{array}$ & -.024 & .083 & $.259 * *$ & .017 & $.472 * *$ & $.209 *$ \\
\hline & Sig. (2-tailed) & .816 & .410 & .009 & .864 & .000 & .037 \\
\hline & $\mathrm{N}$ & 100 & 100 & 100 & 100 & 100 & 100 \\
\hline \multirow{3}{*}{ Analytics } & $\begin{array}{c}\text { Pearson } \\
\text { Correlation }\end{array}$ & .101 & $.291 * *$ & $.313 * *$ & -.052 & .109 & $.416^{* *}$ \\
\hline & Sig. (2-tailed) & .317 & .003 & .002 & .608 & .279 & .000 \\
\hline & $\mathrm{N}$ & 100 & 100 & 100 & 100 & 100 & 100 \\
\hline \multirow{3}{*}{$\begin{array}{c}\text { Business } \\
\text { Reporting }\end{array}$} & $\begin{array}{c}\text { Pearson } \\
\text { Correlation }\end{array}$ & $.441 * *$ & $.253^{*}$ & .185 & .087 & $-.275^{* *}$ & $.223 *$ \\
\hline & Sig. (2-tailed) & .000 & .011 & .065 & .388 & .006 & .026 \\
\hline & $\mathrm{N}$ & 100 & 100 & 100 & 100 & 100 & 100 \\
\hline
\end{tabular}

Author's Computation, 2017

Table 2: Analysis of Relationship between Customer Relationship Management and Micro, Small and Medium Enterprises (MSMEs) Growth

\begin{tabular}{|c|c|c|c|}
\hline & \multicolumn{3}{|c|}{ BUSINESSGROWTH } \\
\hline CRMCOMPONENTS & $\begin{array}{l}\text { Pearson. } \\
\text { Sig. (2-tailed). } \\
\text { N }\end{array}$ & 000 & $\begin{array}{r}346 \\
100 \\
\end{array}$ \\
\hline
\end{tabular}

Author's Computation, 2017 
Table 3: Regression Analysis on CRM Components and MSMEs Growth *ANOVA ${ }^{\text {a) }}$

\begin{tabular}{|c|c|c|c|c|c|c|c|c|c|}
\hline \multicolumn{10}{|c|}{ Model Summary } \\
\hline \multirow[t]{2}{*}{ Model } & \multirow[t]{2}{*}{$\mathrm{R}$} & \multirow{2}{*}{$\begin{array}{c}\mathrm{R} \\
\text { Square }\end{array}$} & \multirow{2}{*}{$\begin{array}{c}\text { Adjusted R } \\
\text { Square }\end{array}$} & \multirow{2}{*}{$\begin{array}{l}\text { Std. Error } \\
\text { of the } \\
\text { Estimate }\end{array}$} & \multicolumn{5}{|c|}{ Change Statistics } \\
\hline & & & & & $\begin{array}{l}\text { R Square } \\
\text { Change }\end{array}$ & $\begin{array}{c}\mathrm{F} \\
\text { Change }\end{array}$ & df1 & $\mathrm{df} 2$ & $\begin{array}{c}\text { Sig. F } \\
\text { Change }\end{array}$ \\
\hline 1 & $.612^{\mathrm{a}}$ & .375 & .334 & 3.696 & .375 & 9.281 & 6 & 93 & .000 \\
\hline
\end{tabular}

a. Predictors: (Constant), Business Reporting, CRM_APPLICATION, Marketing, Customer Care, Analytics, Human Resource

Author's Computation, 2017

Table 4:

ANOVA $^{\mathrm{a}}$

\begin{tabular}{|rl|r|r|r|r|r|}
\hline \multicolumn{2}{|c|}{} & Sum of Squares & df & Mean Square & F & \multicolumn{1}{c|}{ Sig. } \\
\hline & Regression & 760.544 & 6 & 126.757 & 9.281 & $.000^{\mathrm{b}}$ \\
1 & Residual & 1270.206 & 93 & 13.658 & & \\
& Total & 2030.750 & 99 & & & \\
\hline
\end{tabular}

a. Dependent Variable: BUSINESSGROWTH

b. Predictors: (Constant), Business Reporting, CRM_APPLICATION, Marketing, Customer Care, Analytics, Human Resource

Table 5

Coefficients $^{\mathrm{a}}$

\begin{tabular}{|c|c|c|c|c|c|c|c|}
\hline \multirow[t]{2}{*}{ Model } & \multicolumn{2}{|c|}{$\begin{array}{c}\text { Unstandardized } \\
\text { Coefficients } \\
\end{array}$} & \multirow{2}{*}{$\begin{array}{l}\text { Standardized } \\
\text { Coefficients } \\
\text { Beta }\end{array}$} & \multirow[t]{2}{*}{$\mathrm{t}$} & \multirow[t]{2}{*}{ Sig. } & \multicolumn{2}{|c|}{$\begin{array}{c}95.0 \% \text { Confidence } \\
\text { Interval for B }\end{array}$} \\
\hline & B & $\begin{array}{l}\text { Std. } \\
\text { Error }\end{array}$ & & & & $\begin{array}{l}\text { Lower } \\
\text { Bound }\end{array}$ & $\begin{array}{l}\text { Upper } \\
\text { Bound }\end{array}$ \\
\hline (Constant) & 42.119 & 8.345 & & 5.047 & .000 & 25.548 & 58.691 \\
\hline Marketing & .246 & .241 & .090 & 1.021 & .310 & -.232 & .724 \\
\hline Customer Care & -.532 & .163 & -.334 & 3.257 & .002 & -.856 & -.207 \\
\hline CRM_APPLICATION & 1.536 & .459 & .428 & 3.343 & .001 & .624 & 2.448 \\
\hline HumanResource & .165 & .293 & .062 & .563 & .575 & -.417 & .746 \\
\hline Analytics & .676 & .312 & .227 & 2.169 & .033 & .057 & 1.295 \\
\hline Business Reporting & .601 & .219 & .243 & 2.737 & .007 & .165 & 1.036 \\
\hline
\end{tabular}

a. Dependent Variable: BUSINESSGROWTH

Author's Computation, 2017

http://dx.doi.org/10.19085/journal.sijmd050501 
Table 6: Hierarchical Stepwise Regression on CRM Components and MSMEs Growth

(Model Summary)

\begin{tabular}{|c|c|c|c|c|c|c|c|c|c|c|}
\hline \multirow[b]{2}{*}{ Model } & \multirow[b]{2}{*}{$\mathbf{R}$} & \multirow[b]{2}{*}{$\begin{array}{l}\text { R } \\
\text { Square }\end{array}$} & \multirow[b]{2}{*}{$\begin{array}{l}\text { Adjusted } \\
\mathbf{R} \\
\text { Square }\end{array}$} & \multirow[b]{2}{*}{$\begin{array}{l}\text { Standard } \\
\text { Error of } \\
\text { the } \\
\text { Estimate }\end{array}$} & \multicolumn{5}{|c|}{ Change Statistics } & \multirow[b]{2}{*}{$\begin{array}{l}\text { Durbin- } \\
\text { Watson }\end{array}$} \\
\hline & & & & & $\begin{array}{l}\text { R } \\
\text { Square } \\
\text { Change }\end{array}$ & $\begin{array}{l}\mathbf{F} \\
\text { Change }\end{array}$ & dfi & Df2 & $\begin{array}{l}\text { Sig F } \\
\text { Chamge }\end{array}$ & \\
\hline 1 & $.547 \mathrm{a}$ & $.547 a$ & .262 & 3.891 & .299 & 8.032 & 5 & 94 & .000 & \\
\hline 2 & $.541 b$ & $.541 \mathrm{~b}$ & .263 & 3.888 & -.006 & .854 & 1 & 94 & .358 & \\
\hline 3 & $.606 \mathrm{c}$ & $.606 \mathrm{c}$ & .334 & 3.697 & .075 & 11.077 & 1 & 94 & .001 & 2.166 \\
\hline
\end{tabular}

a. Predictors: (Constant), Business Reporting, Human Resource, Marketing, Customer Care, Analytics

b. Predictors: (Constant), Business Reporting, Human Resource, Customer Care, Analytics c. Predictors: (Constant), Business Reporting, Human Resource, Customer Care, Analytics, CRM Application Package

d. Dependent Variable: BUSINESSGROWTH

Author's Computation, 2017

Table 7: Hierarchical Stepwise Regression on CRM Components and MSMEs Growth *ANOVAa)

\begin{tabular}{|l|l|l|l|l|l|l|}
\hline Model & $\begin{array}{l}\text { Sum of } \\
\text { Squares }\end{array}$ & $\mathrm{df}$ & $\begin{array}{l}\text { Mean } \\
\text { Square }\end{array}$ & $\mathrm{F}$ & Sig. & $\begin{array}{l}\text { Sum of } \\
\text { Squares }\end{array}$ \\
\hline 1 & Regression & 607.871 & 5 & 121.574 & 8.032 & $.000 \mathrm{~b}$ \\
& Residual & 1422.879 & 94 & 15.137 & & \\
2 & Total & 2030.750 & 99 & & & \\
& Regression & 594.940 & 4 & 148.735 & 9.841 & $.000 \mathrm{c}$ \\
& Residual & 1435.810 & 95 & 15.114 & & \\
3 & Total & 2030.750 & 99 & & & $.000 \mathrm{~d}$ \\
& Regression & 746.298 & 5 & 149.260 & 10.923 & \\
& Residual & 1284.452 & 94 & 13.664 & & \\
& Total & 2030.750 & 99 & & & \\
\hline
\end{tabular}

a. Dependent Variable: BUSINESSGROWTH

b. Predictors: (Constant), Business Reporting, Human Resource, Marketing, Customer Care, Analytics

c. Predictors: (Constant), Business Reporting, Human Resource, Customer Care, Analytics

d. Predictors: (Constant), Business Reporting, Human Resource, Customer Care, Analytics, CRM Application Package

Author's Computation, 2017

http://dx.doi.org/10.19085/journal.sijmd050501 
Table 8: Coefficient Table for Regression Analysis on CRM Components and MSMEs Growth

\begin{tabular}{|c|c|c|c|c|c|c|}
\hline & \multirow[b]{2}{*}{ Model } & \multicolumn{2}{|c|}{ Unstandardized Coefficient } & \multirow{2}{*}{$\begin{array}{l}\text { Standardized } \\
\text { Coefficient } \\
\text { Beta }\end{array}$} & \multirow[b]{2}{*}{$\mathrm{t}$} & \multirow[b]{2}{*}{ Sig } \\
\hline & & $\mathrm{B}$ & $\begin{array}{l}\text { Standard } \\
\text { Error }\end{array}$ & & & \\
\hline 1 & $\begin{array}{l}\text { (Constant) } \\
\text { Marketing } \\
\text { Customer Care } \\
\text { Human Resource } \\
\text { Analytics } \\
\text { Business Reporting }\end{array}$ & $\begin{array}{l}32.490 \\
.234 \\
-.255 \\
.744 \\
.841 \\
.517\end{array}$ & $\begin{array}{l}8.245 \\
.253 \\
.148 \\
.248 \\
.324 \\
.230\end{array}$ & $\begin{array}{l}.085 \\
-.160 \\
.280 \\
.282 \\
.209\end{array}$ & $\begin{array}{l}3.940 \\
.924 \\
-1.723 \\
2.994 \\
2.594 \\
2.254 \\
\end{array}$ & $\begin{array}{l}.000 \\
.358 \\
.088 \\
.004 \\
.011 \\
.027\end{array}$ \\
\hline 2 & $\begin{array}{l}\text { Constant) } \\
\text { Customer Care } \\
\text { Human Resource } \\
\text { Analytics } \\
\text { Business Reporting }\end{array}$ & $\begin{array}{l}37.292 \\
-.281 \\
.738 \\
.941 \\
.506\end{array}$ & $\begin{array}{l}6.398 \\
.146 \\
.248 \\
.305 \\
.229\end{array}$ & $\begin{array}{l}-.176 \\
.278 \\
.316 \\
.205\end{array}$ & $\begin{array}{l}5.829 \\
-1.928 \\
2.972 \\
3.083 \\
2.209\end{array}$ & $\begin{array}{l}.000 \\
.057 \\
.004 \\
.003 \\
.030\end{array}$ \\
\hline 3 & $\begin{array}{l}\text { (Constant) } \\
\text { Customer Care } \\
\text { Human Resource } \\
\text { Analytics } \\
\text { Business Reporting } \\
\text { CRM Application } \\
\text { Package }\end{array}$ & $\begin{array}{l}47.116 \\
-.557 \\
.161 \\
.782 \\
.588 \\
1.529\end{array}$ & $\begin{array}{l}6.762 \\
.161 \\
.293 \\
.294 \\
.219\end{array}$ & $\begin{array}{l}-.350 \\
.061 \\
.263 \\
.238 \\
.426\end{array}$ & $\begin{array}{l}6.968 \\
-3.451 \\
.550 \\
2.659 \\
2.684 \\
3.328\end{array}$ & $\begin{array}{l}.000 \\
.001 \\
.584 \\
.009 \\
.009 \\
.001\end{array}$ \\
\hline
\end{tabular}

Author's Computation, 2017

\section{Test of Hypotheses}

1. Ho: There is no statically significant relationship between Customer relationship Management and MSMEs Growth in Southwest Nigeria.

Ha: There is a statically significant relationship between Customer Relationship Management and MSMEs Growth in Southwest, Nigeria

2. Ho: There is no statistically significant influence on customer relationship management (CRM) on MSMEs growth in Southwest, Nigeria.

Ha: There is a statistically significant influence of customer relationship management (CRM) on MSMEs growth in Southwest, Nigeria.

The conjectural statements above in the study were tested and the null hypotheses were rejected. For hypothesis one, it was found that a statistically significant relationship exists between customer relationship management and MSMEs growth in Southwest, Nigeria $(r=0.35, p=0.000)$ see table 2 above. For the second hypothesis, the null hypothesis was also rejected as it was also found out that there was a statistically significant influence of customer relationship management on MSMEs growth $(\mathrm{F}=10.923, \mathrm{p}=0.000)$ see table 7 .

\section{Discussion of Findings and Implication for Practice}

The study identified the components of Customer Relationship Management among Micro, Small, and Medium Enterprise in Southwest, Nigeria - human resource management, customer care, analytics, marketing, and business reporting. The Cronbach's Alpha was computed to ascertain the internal reliability of the items used to measure CRM components and factors of growth. The 
values of the Cronbach's Alpha were 0.671 and 0.66 .2 respectively and were considered to be strong enough (Hair, Anderson, Tatham, \& Black, 2008).

The correlational analysis (see table 1) shows a statistically significant relationship between customer care and customer retention, public image maintenance and business revenue $(r=0.430$, $\mathrm{p}<0.05),(\mathrm{r}=0.438, \mathrm{p}<0.05),(\mathrm{r}=0.392, \mathrm{p}<0.05)$ respectively. The analysis also revealed a significant relationship between human resource factor and business revenue, product development as well as product market development $(r=0.209, p<0.05),(r=0.259, p<0.05),(r$ $=0.472, p<0.05)$ respectively. The analysis further showed a statistically significant relationship between analytics and business revenue, product development, and customer retention $(r=0.416$, $\mathrm{p}<0.05)$ and $(\mathrm{r}=0.313, \mathrm{p}<0.05)$ respectively. There was significant relationship between marketing and business revenue $(r=0.214, \mathrm{p}<0.05)$ respectively.

Furthermore, the results revealed the predictor variables with a unique contribution to MSMEs growth in southwest Nigeria. These factors are customer care, analytics, and business reporting $(\mathrm{B}=-0.350, \mathrm{p}<0.001) ;(\mathrm{B}=0.263, \mathrm{p}<0.009) ;(\mathrm{B}=0.238, \mathrm{p}<0.009)$ respectively. Marketing and human resource did not show a unique contribution to the variation in the growth of MSMEs in the study area $(\mathrm{B}=0.085, \mathrm{p}<0.358)$ and $(\mathrm{B}=0.061, \mathrm{p}<0.584)$ respectively. Invariably, the two components- marketing and human resource should be given utmost attention to further boost the relationship between suppliers and customers for the enhancement of the customer base which could lead to MSMEs growth. It was also found that all the CRM components examined as an omnibus concept had a statistical significant influence on MSMEs growth in Southwest Nigeria ( $R$ square $=0.375$, adjusted $\mathrm{R}$ square $=0.334, \mathrm{p}<0.001$ ). This implies that $33.4 \%$ variation in MSME growth was induced by CRM components in the study area. The use of CRM application software as opined by previous researchers on customer relationship management would not be sufficient to boost the customer base of MSMEs in Nigeria. It was found in this study that when the use of CRM technology was considered as a confounding variable using hierarchical regression model, the factors of customer relationship management such as marketing, human resource, analytics, business reporting and customer care were found to be responsible for $33 \%$ of the variation in the growth of MSMEs in Southwest, Nigeria. This finding aligns with the work of Coltman, Devinney and Midgley (2011) who opined that the impact of IT infrastructure on superior CRM capability is indirect and fully mediated by human analytics and business architecture. Also, it was discovered that the cost implication of installing any CRM technology, clients desire to be treated like a unique individual as well as literacy level of customers and MSMEs operators in Nigeria in the use of CRM technology observed to be shallow, made most MSMEs yet to subscribe to its implementation.

\section{Conclusion and Recommendation}

This study assessed the factors of Customer Relationship Management and its influence on the growth of Micro, Small, and Medium Enterprises in Southwest, Nigeria. The respondents were the employees and owners of the enterprises in the study. The study incontrovertibly revealed the nexus between Customer Relationship Management and the MSMEs growth. The study as well showed the factors that uniquely contributed to building a vast customer base and growth of MSMEs in the study area; these factors are customer care, analytics, and business reporting. The study concludes that marketing drives, as well as the need to enhance workers on the effective ways to handle their clients, is paramount for a better customer base to continually foster MSMEs growth in Nigeria. Building a vast customer base will be realistic if the use of CRM technology combined with the interaction among the components of CRM - customer care, human resource, marketing, analytics and business reporting. 


\section{References}

[1]. Alireza, Mostafa and Kazem (2011) Customer Relationship Management in Small-medium Enterprises: The case of science and technology parks of Iran African Journal of Business Management Vol.5 (15), pp. 6159-6167, DOI: 10.5897/AJBM10.695 ISSN: 1993-8233

[2]. Basil. O (2005) Small and Medium Enterprises (SMEs) in Nigeria: Problems and Prospects. A Dissertation Submitted to the St. Clements University in Partial Fulfilment of the Requirements for the Award of the Degree of Doctor of Philosophy in Management

[3]. Bhatia, S.C. (2008) "Retail Management" John Wiley \& Sons

[4]. Coltman, T., Devinney, T. M. \& Midgley, D. F. (2011). Customer Relationship Management and Firm Performance Journal of Information Technology, 26 (3), 205-219. University of Wollongong Research

[5]. Cox, E. (2011) "Retail Analytics: The Secret Weapon” John Wiley \& Sons

[6]. Goldenberg, B.J. (2008) "CRM in Real Time: Empowering Customer Relationships" Information Today, Inc.

[7]. Håkan, H. (Ed.) 1982 International Marketing and Purchasing of Industrial Goods. An Interaction Approach. John Wiley \& Sons, Ltd

[8]. Krejcie, F. \& Morgan .A (1960) Small-Sample Techniques. The NEA Research Bulletin, Vol. 38 (December, 1960), p. 99.

[9]. Lamb, C.W., Hair, J.F. \& McDaniel, C. (2011) "Marketing: Student Edition” Cengage Learning

[10].Mueller, B. (2010) "Dynamics of International Advertising: Theoretical and Practical Perspectives" Peter Lang

[11].Peppers, D. \& Rogers, M. (2011) "Managing Customer Relationships: A Strategic Framework" John Miley \& Sons

[12]. "Unlock the Mysteries of Your Customer Relationships". Harvard Business Review. Retrieved 22 November 2017. 